\title{
UNINTENDED CONSEQUENCES? \\ WELFARE REFORM AND THE WORKING POOR
}

\author{
Ann Dryden Witte \\ Magaly Queralt \\ Tasneem Chipty \\ Harriet Griesinger \\ Working Paper 6798 \\ http://www.nber.org/papers/w6798
NATIONAL BUREAU OF ECONOMIC RESEARCH 1050 Massachusetts Avenue
Cambridge, MA 02138
November 1998

This paper is a product of the Tri-State and Wellesley/FIU Child Care Research Partnerships and of the Child Care Bureau's Child Care Policy Research Consortium. Our work was made possible by Grants 90YE0001 and 90YE006 from the Child Care Bureau, Administration for Children \& Families, Department of Health and Human Services (DHHS). The work has benefited substantially from the comments of Susan Muenchow, Director of the Florida Children's Forum, Pernella Burke, former Director of Dade's Office of Child Development Services, Pia Divine of the Child Care Bureau and members of the Child Care Policy Research Consortium. The opinion and conclusions of the paper should not be attributed to DHHS or to any of our state or local partners. The authors alone remain responsible for all errors. The views expressed here are those of the author and do not reflect those of the National Bureau of Economic Research.

(c) 1998 by Ann Dryden Witte, Magaly Queralt, Tasneem Chipty, and Harriet Griesinger. All rights reserved. Short sections of text, not to exceed two paragraphs, may be quoted without explicit permission provided that full credit, including $(\mathcal{O}$ notice, is given to the source. 
Unintended Consequences?

Welfare Reform and the Working Poor

Ann Dryden Witte, Magaly Queralt,

Tasneem Chipty, and Harriet Griesinger

NBER Working Paper No. 6798

November 1998

JEL No. H53, I38, J13

\begin{abstract}
We have used a unique longitudinal database that incorporates information from diverse administrative and research sources to examine the impact of the early stages of welfare reform on poor working families who do not receive cash assistance. Our data are for 2791 working poor families from March 1996 through February 1997. Using a number of different estimation techniques, we find that the impact of the simultaneous October 1996 implementation of welfare reform and a federal minimum wage increase was to lower the earnings of the working poor families in our sample by approximately $6 \%$. We find that increases in funding for Child Care Subsidies associated with welfare reform led to a significant increase in earnings. On net, the increase in Child Care Subsidies and the decrease in earnings because of the October 1996 changes approximately cancel out, with the representative family in our sample experiencing an estimated monthly earnings change of between $-\$ 18$ and $\$ 68$, with an earnings gain of $\$ 25$ being most likely.
\end{abstract}

\author{
Ann Dryden Witte \\ Deparment of Economics \\ Florida International University \\ 155 Ocean Lane Dr., \#812 \\ Miami, FL 33149 \\ and NBER \\ Awitte@Wellesley.edu \\ Tasneem Chipty \\ Department of Economics \\ Ohio State University \\ 410 Arps Hall \\ 1945 N. High Street \\ Columbus, OH 34210
}

\author{
Magaly Queralt \\ School of Social Work \\ DM234 \\ Florida International University \\ Miami, FL 33199 \\ MQueralt@worldnet.att.net
}

\author{
Harriet Griesinger \\ Department of Economics \\ Wellesley College \\ Wellesley, MA 02048
}




\section{Introduction}

A major reform of the US welfare system occurred on October 1, 1996 when the Personal Responsibility and Work Opportunity Reconciliation Act (PRWORA, P.L. 104-193) became effective. This act abolished Aid to Families with Dependent Children (AFDC) and, along with it, the entitlement of poor families to receive cash assistance. Under PRWORA, the federal government allocates block grants to states to provide Temporary Aid to Needy Families (TANF). States may use block grant funds for TANF programs that meet conditions specified in PROWRA (e.g., no entitlement to assistance, no more than 5 years of assistance).

In this paper, we use a unique longitudinal data set to discern the impact of welfare reform on the earnings of the working poor. Both academic and policy interest have concentrated on changes in the behavior of the population receiving cash assistance as a result of welfare reform. Little attention has been given to the impact of welfare reform on the large group of low-income working families, many of whom are eligible for cash assistance but do not received it. Here, we study this important but largely overlooked group, which for convenience, we refer to as the "working poor."

Our work focuses on welfare reform in the state of Florida, Florida's Welfare Reform law, generally referred to as the "Work and Gain Economic Self-Sufficiency (WAGES) Act," became effect on October 1, 1996. In Florida, as in other states, welfare reform brought with it a myriad of associated policy and administrative changes. We document the nature of these changes and their impact in Dade County, which contains the Miami metropolitan area and rural farming areas that make extensive use of migrant labor. Important policy changes under the WAGES program include the mandatory return of new parents to work activities much sooner than under AFDC and an increase in the state's child care budget to help parents cope with the transition from welfare to work. In addition to welfare reform, October 1, 1996 was the effective date of the national increase in the minimum wage, from $\$ 4.25$ per hour to $\$ 4.75$ per hour.

We estimate the effects of a set of policy and administrative variables on the earnings of the working poor families in our sample. To briefly preview our results, we find that Florida's October 1, 1996 welfare reform and the simultaneous increase in the federal minimum wage are

\footnotetext{
${ }^{1}$ Many families receiving cash assistance also work.
} 
associated with a significant decline in the earnings of the working poor families in our sample. We cannot separate the effects of welfare reform and the minimum wage increase, but we suspect that the major cause of the decline in earnings of the working poor resulted from the large influx of former welfare recipients into the low-income labor market. We find that the large increase in child care subsidies associated with Florida's welfare reform resulted in a significant increase in the earnings of the working poor. During the early stage of welfare reform in Florida, the positive impact of increase in child care subsidies on the earnings of the working poor approximately offsets the negative impact of welfare reform and the minimum wage increase.

Point estimates indicate that the net effect of all of these was to an increase in monthly earnings of a representative member of our sample by $\$ 25$.

The outline of the paper is as follows. In the next section, we describe in more detail the setting of the study, including a description of the WAGES program and Dade, County Florida. Section III describes the data used to determine the impact of welfare reform on the earnings of the working poor. Section IV outlines the empirical model that underlies our estimations. Section V describes the estimation techniques and Section VI contains our discussion of empirical results. The final section of the paper contains our conclusions and suggestions for further research on the impacts of welfare reform.

\section{The Setting}

\section{A. Florida's Welfare Reform-WAGES}

Florida's Welfare Reform law (Chapter 414 of the Florida Statutes), generally referred to as the "Work and Gain Economic Self-Sufficiency (WAGES) Act," became effective October 1, 1996. The WAGES program is designed to provide temporary assistance to needy families with children (i.e., those with incomes less than or equal to $130 \%$ of the federal poverty level [FPL]) and to provide parents with job preparation, work opportunities, and support services to enable them to become economically self-sufficient.

The WAGES law requires that each adult WAGES recipient not otherwise exempt must participate in work activities for the maximum number of hours allowed under federal law. Applicants must be referred for employment at the time they apply for benefits. Florida's welfare reform is what is called in the literature a "work first" program. Jobs are central and 
welfare recipients are encouraged to move into jobs as rapidly as possible. Those exempt from work activities include: a) custodial parents with children under three months of age; b) recipients who are minor children under age 16; c) those eligible for benefits under Supplemental Security Income (SSI) due to age or disability; and d) custodial parents age 19 and younger who have not completed high school or equivalent who may be required to attend educational activities.

The requirement that custodial parents participate in work activities as soon as their youngest child is three months old is unusually stringent. Under Florida's AFDC program, cash recipients were required to participate in work or other approved activities only when their youngest child was three years old.

To facilitate implementation of WAGES, the law decrees that employment counseling (provided by Florida's Department of Labor and Employment Security) and determination of eligibility for benefits (WAGES, Food Stamps, Medicaid, Child Care Subsidies) be consolidated in a single office. These consolidated offices are referred to as "One-Stop Centers."

Florida's WAGES benefits are low. For example, a WAGES family of three, without housing subsidies, can receive a maximum of $\$ 303$ per month $(\$ 3,636$ per year) in cash assistance. This amounts to less than 30 percent of the 1995 Federal Poverty Level (FPL). Cash assistance under WAGES is limited to 24 consecutive months in any 60 -month period. No adult participant may receive payments for more than 48 months.

\section{B. Dade County Florida}

Dade County has a population of over 2 million. Fifty-five percent of the population in 1996 was Hispanic, 25 percent non-Hispanic white, and 20 percent was black (US Bureau of the Census, 1997). The largest Hispanic groups in the area are from Cuba, Colombia and Nicaragua. The black community is split between Afro-Americans and Caribbean blacks. Haitians form a large part of the Caribbean black population and constitute the poorest segment of that population in Miami.

Dade County is an area of extreme contrasts. The area has a very high poverty rate for children (approximately $38 \%$ ), that afflicts disproportionately and about equally the black and Latino population (particularly recent immigrants). Dade's poorest areas range from Hispanic communities like Little Havana (predominately Cuban and Central American) to native black 
communities such as Liberty City and Overtown, to Haitian-American communities like Little Haiti, and migrant farm worker areas such as Homestead and Florida City. The area also has pockets of incredible wealth, such as Fisher Island, and is a destination point for many "jet setters." Median household income is only $\$ 26,743$ (US Bureau of the Census, 1997).

Dade County has received relatively little attention from academic researchers to date, and yet it is one of the poorest and most racially and ethnically diverse areas in the US. As close observers of the scene describe it: "The multilingual, multicultural experiment that is Miami holds important lessons for what the American city will be about in a changed world " (Portes and Stepick, 1993, p.xvi).

\section{The Data}

To examine the impact of welfare reform on the earnings of working poor families who do not receive cash assistance, we use a unique longitudinal database that we create by combining data from a large number of sources. Our sources include: (1) records used to administer federal/state Child Care Subsidies in Dade County, (2) child care provider records of the resource and referral agency that provides information on child care options to parents in Dade County, (3) employer data collected by the Florida Department of Labor in connection with the Unemployment Insurance program (i.e., ES202 data) (4) Florida Department of Labor data collected under its local area employment statistics program (the LAUS program), (4) administrative records for the Florida Department of Children and Families, (5) administrative records from the Dade County public schools, (6) administrative and programmatic records from United Way of Dade County, (7) interviews with personnel at all offices determining welfare eligibility in Dade county, (8) the 1990 U.S. Census and (9) the U.S. Bureau of Labor Statistics cost of living indexes. See Table 1 for a listing of the variables we use and their sources.

Our observations on the earnings and other characteristics of working poor families come from the database used to administer the federal/state Child Care Subsidy programs in Dade County. Under the Family Support Act and now PRWORA, working poor families who do not receive cash assistance are eligible to receive child care subsidies for their children under age 13 if they are "at-risk" of becoming welfare dependent. States define families as being "at-risk" of welfare dependency based on income levels and family size. Income levels used are either based on the Federal Poverty Level (FPL) or are a percent of state median income. Because 
eligibility is determined by income level, these working poor families are called "incomeeligible."

Working poor families in Florida are eligible for child care subsidies if their incomes are below $150 \%$ of the FPL. Most families that receive Income Eligible Child Care Subsidies have incomes and family structures that appear to make them eligible for cash assistance. Indeed, most of these families have monthly incomes that, even if sustained for an entire year, would not lift them above the FPL. However, these families differ significantly from families receiving cash assistance in characteristics other than income. Specifically, they are significantly more likely to be Latino or Haitian-American and to speak a language other than English at home. They are also significantly more likely to live in communities with large numbers of recent immigrants. Anecdotal evidence suggest that the failure to apply for cash assistance relates both to lack of knowledge of cash assistance programs and to social stigma associated with acceptance of cash assistance in some of Dade County's immigrant communities. In our conversations with families in Dade's new immigrant communities; we learned that many are willing to "take money for their children, but not for themselves."

Because eligibility for Income-Eligible Child Care Subsidies depends both on income and family structure, the data collected to administer this child care subsidy program is quite extensive. We were given access to these data as members of the Tri-State Child Care Policy Research Partnership. ${ }^{2}$ Beginning in March 1996, we received monthly "snapshots" of Dade County's Income-Eligible Child Care Subsidy database. Information available in the Subsidy database includes: earnings on up to three jobs, information on family structure, and sociodemographic information (e.g., age, sex, marital status, race, country of origin) on up to eleven family members. We collected 24,436 monthly observations on 2,791 families. Our data are for the period March 1996 through February 1997.

We were also given monthly snapshots of Dade County's Child Care Resource and Referral database. This database contains extensive information about all licensed and registered child care providers. The database is used to provide information to parents on the child care

\footnotetext{
2 The Tri-State research partnership is a partnership of university researchers, state and local policy makers, and state and local child care administrators. It is one of several initiatives by the US Department of Health and Human Services intended to foster better research on low-income families and their economic struggle towards self sufficiency. As members of this partnership, we have worked closely with state and local administrators in Alabama, Florida and Massachusetts.
} 
options available to them.

Like all data, administrative data have both strengths and weaknesses. Strengths include continual updating and large enough samples to allow finer small area analysis than is generally possible with research databases. Weaknesses include sample and variable selection.

One potential benefit of our administrative sample is that the families we study are more likely to be similar in their unobservable characteristics than are families in a random sample of the population. The families in our sample are virtually all headed by a female single parent, facing economic hardship, and facing a similar set of employment choices. See Table 1 for descriptive statistics for our sample.

A drawback of our administrative sample is the potential for sample selection bias. Selection bias will be a problem if unobservable characteristics, which make people more likely to know about and apply for child care subsidies, are correlated with unobservables in the earnings model we estimate. While we are aware of this issue, we are unable to resolve it for at least two reasons. First, we can not correct directly for sample selection bias because we do not observe income-eligible families who do not apply for Income-Eligible Child Care Subsidies. Second, we are unable to rely on the literature because as far as we are aware, there has been no study of the factors associated with participation in child care subsidy programs. ${ }^{3}$

The Dade County Child Care subsidy and R\&R databases provide only part of the information needed to estimate the reduced form model for earnings described in the next section. In addition to the information in these administrative databases, we require information on: (1) policy and administrative changes, (2) other early childhood education (ECE) and child care subsidies programs, (3) local communities, (3) the costs of working and (4) the local labor market.

Our state and local Partners were able to supply us with information on policy and administrative changes in state/federal Child Care Subsidy programs. We obtained information on ECE programs directly from the Community Action Agency that runs Head Start in Dade County and from the Dade County public schools which administers Pre-Kindergarten programs and some Head Start programs. The major source of private child care subsidies in Dade County

\footnotetext{
${ }^{3}$ There is a growing literature on factors associated with use of cash assistance, food stamps and Medicaid. However, given the unique characteristics of families receiving income-eligible child
} 
is United Way. We worked with United Way to obtain the amount of funds that they allocated to each of their subsidized providers and to determine which children were eligible for subsidies under each program.

We were able to follow the implementation of Florida's welfare reform because the first author was a member of the Research and Evaluation Subcommittee of the WAGES Coalition of Dade and Monroe Counties. The WAGES Coalition is the public/private committee overseeing welfare reform in Dade County.

We were able to obtain information on the local labor market and on the earnings of child care workers in Dade County using the ES202 and other Florida Department of Labor data bases. The ES202 data were provided as part of a special contractual agreement between Dade County's state university, Florida International University, and the Florida Department of Labor.

Table 1 lists all variables used in the analysis and gives sources for each and Table 2 provides descriptive statistics.

\section{Empirical Model}

Our empirical model is a reduced form model for the earnings of the low-income workers in our sample. To specify the vector of socio-demographic and human capital variables, we draw on the existing literature on the earnings of low-income families. See Blank (1997), Eissa and Liebman (1996), Harris (1996), Kim and Mergoupis (1997) and Pavetti and Acs (1997) for recent examples and reviews of previous literature. To develop exogenous measures that reflect administrative and policy changes, we follow Eissa and Liebman (1996), Meyer and Rosenbaum (1997) and Moffitt (1992). To be specific, we model the log of monthly earnings (LNEarn) as a function of human capital and socio-demographic variables $(\mathrm{H})$, policy variables (Policy), administrative variables (A), the costs of working (C), local labor market conditions (LM) and a community-specific fixed effect:

$$
L N E a r n=H \beta+\text { Policy } \delta+A \gamma+C \phi+L M \varphi+\text { Community } \gamma+\varepsilon
$$

care subsidies in Dade County, this literature provides only limited guidance. For a recent example of this work and a literature survey, see Blank and Ruggles (1996). 
The parameters of primary interest are associated with the Policy variables, which include an indicator variable for October 1, 1996 marking the simultaneous implementation of welfare reform and the increase in the minimum wage and a set of variables reflecting child care subsidy and early childhood education (ECE) programs.

\section{A. Interpretation of Joint Effects of Welfare Reform and the Minimum Wage Increase}

Since both Florida's Welfare Reform and a $\$ .50$ per hour increase in the minimum wage (from $\$ 4.25$ to $\$ 4.75$ ) took effect on October 1,1996 , we are unable to unambiguously determine the independent effect of each change. However, using the large literature on the effect of minimum wage increases and information on the effect of welfare reform in Dade County, we are able to rule out certain things. See Card and Krueger $(1995,1998)$ and Abowd, et al. (1998) for surveys.

The general conclusion of the literature on the effects of minimum wage increases is that such increases will raise the earnings of low-income workers who are: (1) covered by the minimum wage legislation and (2) earn incomes between the old and new minimum wage. Workers earning slightly more than the new minimum wage may also see an increase in their wages, as employers seek to maintain pay differentials among their low-income employees. A more controversial issue is the possible effect of increases in the minimum wage on the availability of jobs for low-income workers. Most economists believe that increases in the minimum wage will decrease the availability of jobs for low-income workers. However, some recent research suggests that increases in the minimum wage may have no significant effect on the availability of jobs.

The intent of Florida's welfare reform is to increase the rate of employment among welfare recipients. There is both descriptive and analytic evidence to indicate that even in its early stages, Florida's welfare reform has increased the probability that welfare recipients would work. In March 1996, 59\% of current and former welfare recipients receiving Child Care Subsidies were working, while in February 1997, 74\% were working. Witte, et al. (1998) report that controlling for a large range of other factors, the joint occurrence of Florida's welfare reform and the minimum wage increase was associated with a $1 \%$ increase in the probability that a welfare recipient in Dade County would work. 
During the period of our study, there was a precipitous decrease in the number of families receiving cash assistance in Dade County. Specifically, in Dade and Monroe Counties, welfare caseloads peaked at approximately 220,000 in the fall of 1995 and declined to approximately 110,000 in March $1998{ }^{4}$ The rate of decline in caseloads accelerated with Welfare Reform in the fall of 1996. We are in the process of following up a sample of these "dropouts" from welfare reform. Our work to date indicates that $44 \%$ of these dropouts are working.

Using the above information on the increase in employment for welfare recipients and the number of welfare "drop outs" obtaining jobs, we estimate that changes associates with the early stages of welfare reform increased Dade County's employed population by approximately $5 \%$. The effect of this large influx of workers was concentrated in certain employment sectors (e.g, non-durable manufacturing, retail and wholesale trade and services). During the period of this influx, the number of jobs in Dade County grew by less than $2 \%$.

To summarize, we would expect the minimum wage increase to increase earnings of lowincome workers. The minimum wage increase might also decrease either the number of hours of work or the number of low-wage jobs available. Welfare reform caused a large influx of lowwage workers into the job market. In the early stages of welfare reform, this influx occurred mainly because many families stopped receiving cash assistance and went to work.

If we find that the simultaneous increase in the minimum wage and welfare reform leads to an increase in earnings for the working poor, the most likely explanation is the increase in the minimum wage. However, if we find that the simultaneous increase in the minimum wage and welfare reform leads to a decrease in earnings for the working poor, interpretation is ambiguous. Earnings may have declined both because of reduced hours caused by the minimum wage increase and decreased hours and/or wages due to the influx of low-skill workers into the labor market associated with welfare reform.

\footnotetext{
${ }^{4}$ We obtained our information on caseloads from the District 11 office of Florida's Department of Children and Families. District 11 includes Dade and Monroe Counties. Monroe County covers the Florida Keys. However, the overwhelming majority of welfare clients in these two counties come from Dade rather than Monroe County.
} 


\section{B. Child Care Subsidy and ECE Programs}

As far as we are aware, there has been no previous study that examines the impact of the availability of child care subsidies and ECE programs on the earnings of low-income families. This may not be surprising for, at least, two reasons . First, funding for child care subsidies only became substantial after passage of the Family Support Act in 1988. Second, until PRWORA, child care subsidy programs were funded from a bewildering array of sources and programs differed substantially across states. Child care subsidies are central to welfare reform and have received increased funding as a result of welfare reform.

\section{Federal/State Child Care Subsidy Programs}

In Florida, working parents with children under age 13 and incomes below $150 \%$ of the FPL are eligible to receive child care subsidies under Florida's Income-Eligible Child Care Subsidy program. These low-income families may continue to receive subsidies until their incomes exceed $185 \%$ of the FPL.

Families receiving child care subsidies under the Income Eligible program are required to pay part of the cost of care for their children. The amount of these "co-payments" depends on family income and family size.

To reflect important aspects of the Income-Eligible Child Care Subsidy program, we include the following variables in our specification: (1) the State/Federal Child Care Subsidy funding available per child eligible for subsidy, (2) the average rate at which parental copayments for child care increase as income increases and (3) a variable that reflects the fact that co-payments for care of a second and subsequent children are only half of the co-payment required for the first child in care.

\section{ECE and United Way Subsidies}

There are two major ECE programs operating in Dade County and most other areas of the country-Head Start and Pre-Kindergarten (Pre-K) programs. Head Start was begun in the 1960s as part of the War on Poverty and is funded by direct federal grants to agencies that administer Head Start programs. Many agencies administering Head Start programs, including most agencies in Dade County, have administered Head Start programs since the 1960s. Head Start programs are generally part-day, part-year programs. We distinguish Head Start programs in 
public schools and Head Start programs administered by the Community Action Agency (CAA, an agency established in the 1960s to fight poverty). We also distinguish Head Start programs that provide "wrap-around" care. Such programs provide care before or after the end of the standard Head Start program so that children can remain in care during normal working hours. Our measure of the availability of care is the enrollment in each type of Head Start program per child eligible for care in each zip code in Dade County.

Pre-K programs are associated with public schools and receive their funding from the local school board. We distinguish Pre-K programs that are provided free to four-year-old children living in poverty and Pre- $\mathrm{K}$ programs that charge fees and are available to children less than 13. Our measure of the availability of care in these programs is the enrollment per eligible child in the zip code.

United Way provides subsidies directly to providers in economically distressed communities. Eligibility varies with the program subsidized. For each program subsidized by United Way in Dade County, we calculate the dollar amount of subsidies per child eligible for the particular program.

\section{Estimation}

As is well known, estimation of models using longitudinal data requires use of specialized statistical methods. ${ }^{5}$ In our application where we observe families over time, we are concerned with unobservable family-specific attributes that may enter the earnings equation and thus affect the consistency of the estimation. The most commonly used estimators for longitudinal data are the fixed-effects estimator and the random-effects estimator. The fixedeffects estimator requires that the unobservable-family specific effect be constant or fixed over time. This estimator requires few other assumptions, but is not efficient because it ignores the time-invariant information and baseline values of time-variant information, employing only variation in deviations from family-specific means to estimate parameters.

By way of contrast, the traditional random-effects estimator uses all the information contained in both the time series and cross sectional variation in the data and thus produces more

\footnotetext{
${ }^{5}$ See Chamberlain (1984) or Greene (1997) for more detailed discussions of these
} techniques for estimating models using longitudinal data. 
statistically efficient results than the fixed-effect estimator. However, for consistency, it requires included regressors be uncorrelated with the family-specific effect which is relegated to the error term.

The traditional random-effects estimator has been criticized because it imposes a correlation on the unmeasured random family-specific effects that is constant through time. This is equivalent to the assumption that unmeasured family-specific behavioral patterns have a correlation that is constant across time. Most behavioral models (e.g., Becker's model of habit formation) suggest that while behavior is correlated across time, the level of correlation declines as one moves back in time. That is, most behavioral models would predict that the correlation of the family-specific effect is highest for adjacent time period and declines as time periods are separated by increasingly longer periods. To allow for this possibility, one uses generalized random-effects estimator that imposes no structure on the correlation of the family-specific random effects (Liang and Zeger (1986) and Liang, Zeger and Quqish (1992)).

We estimate parameters of our earnings model using each of the three estimators. ${ }^{6}$ Due to the flux in the Income Eligible Subsidy rolls, our longitudinal data on the working poor is "unbalanced." That is, the number of months of data available for individuals varies. Because the error term for models estimated with unbalanced panel data is heteroskedastic, we use standard errors that are robust to heteroskedasticity.

Columns 2 and 3 of Table 3 contain results for the fixed-effects estimator and the traditional random-effects estimator. We find that these two estimators produce results that are very similar for the variables of primary interest. The Breusch and Pagan Lagrangian multiplier test for random-effects, which is distributed $\chi_{1}^{2}$ under the null hypothesis that the variance of the

\footnotetext{
${ }^{6}$ To be specific, for the underlying model $Y_{i t}=X_{i t} \beta+\alpha_{i}+\varepsilon_{i t}$, the fixed effects estimator minimizes the criterion function: $\mathcal{\alpha}-\tilde{\mathrm{X}} \beta \mathbf{I}^{\prime} \operatorname{Var} \boldsymbol{d} \mathbf{I}^{-1} \mathbf{d}-\tilde{\mathrm{X}} \beta \mathbf{|}$ where $\tilde{\mathrm{Y}}$ and $\tilde{\mathrm{X}}$ are deviations from family-specific means and $\operatorname{Var}(\widetilde{Y})$ is, as usual, a diagonal matrix with diagonal element $i$ equal to the $\operatorname{Var}\left(\varepsilon_{\mathrm{it}}-\varepsilon_{\mathrm{i}}\right)$. Similarly, the random effects estimators minimize the criterion function: (Y $\mathrm{X} \beta)^{\prime} \operatorname{Var}(\mathrm{Y})^{-1}(\mathrm{Y}-\mathrm{X} \beta)$, where $\operatorname{Var}(\mathrm{Y})$ is a block diagonal matrix with symmetric, family-specific $T_{i} \times T_{i}$ matrices on the diagonal. For the traditional random effects estimator, each of these $T_{i} x$ $T_{i}$ matrices has constant covariance parameters $\left(\operatorname{Cov}\left(\alpha_{i, t}, \alpha_{i, t^{\prime}}\right)=\rho\right.$ for all $t$ and $\left.t^{\prime}\right)$ off the diagonal and $\operatorname{Var}\left(\alpha_{\mathrm{i}}+\varepsilon_{\mathrm{it}}\right)$ on the diagonal. The unstructured random effects estimator does not require the off-diagonal covariance parameters to be the same. Rather, as suggested by many behavioral models, it allows $\operatorname{Cov}\left(\alpha_{i, t}, \alpha_{i, t^{\prime}}\right)$ to vary as the length of time between time periods $t$ and $t^{\prime}$ increases.
} 
family-specific random effects is zero, is 45505 . The test strongly rejects zero variance for the family-specific effects, suggesting that the family-specific effect is in fact not constant over time and that some type of random effects model is consistent with the data.

Results for this unstructured random-effects estimator are reported in column 4 of Table 3. The estimated correlation matrix for the family-specific random effect indicates, as suggested by behavioral models, that behavior is most highly correlated for adjacent months (e.g., the unmeasured family-specific effects for February 1997 are most highly correlated with the familyspecific effects for January 1997) and that the correlation of behavior declines as we move back in time. For example, for families that we observe for our entire 12-month study period, the correlation of the unmeasured family-specific effects goes from 1 for January and February 1997 to .39 for March 1996 and February, 1997. The $\chi^{2}$ statistic for the random-effects model with the unstructured errors is much larger than the $\chi^{2}$ statistic for traditional random-effects model. This indicates that the unstructured random-effects model captures patterns in the data that are not accounted for by the traditional random-effects model.

The traditional random-effects model imposes a correlation of .66 for the unmeasured family-specific effects, implying that behaviors in March 1996 and February 1997 are just as correlated as behaviors in January and February 1997. Consequently, the traditional randomeffects model does not reflect the patterns of behavior in the data.

Finally, to improve the efficiency of our estimates, we reduce our specification to the set of variables that minimizes the mean squared error. This is a widely used model selection criterion. See Leamer (1983).

Results for the reduced specification are given in column 5 of Table 3 . We emphasize these results in our discussion below, but the discussion of the impact of welfare reform, the minimum wage increase and Child Care Subsidies would not change radically if we were to use the results in any other column of Table 3. Our results for these variables are robust across the estimation technique and specifications we have used.

\section{Results}

Regardless of estimation technique, we find that the combined effect of the October 1, 1996 minimum wage increase and Florida's welfare reform was to significantly decrease the earnings of working poor families that did not receive cash assistance. 
Results obtained using the unstructured random-effects estimator indicate that the combined effect of the October 1, 1996 minimum wage increase and Florida's welfare reform was to decrease the earnings of working poor families that did not receive cash assistance by approximately $6 \%$. This implies that the monthly earnings of a representative working poor family decreased by between $\$ 35$ and $\$ 78$ with a decline of $\$ 57$ being most likely. This is a substantial decline in income for families that are already living below poverty.

As noted earlier, we cannot say whether it was the employment reducing effects of the minimum wage increase or the increase in the number of low-income workers associated with welfare reform that caused this decline in earnings. However, we strongly suspect that the large increase in the number of low-income workers associated with welfare reform contributed substantially to this decline in earnings.

We find that the increase in federal and state funding for Child Care Subsidies associated with welfare reform was associated with a significant increase in earnings for the working poor families in our sample. Like the previous result, this result is robust across estimation techniques. Results obtained using the unstructured random-effects estimator indicate that a ten percent increase in state/federal funding for child care subsidies is associated with a $4.5 \%$ increase in earnings of the working poor members of our sample. For a representative member of the working poor families in our sample, we estimate that the approximately $\$ 38$ per eligible child increase in child care subsidies funding that we observe to be associated with the early stages of welfare reform would lead to an increase in monthly earnings of between $\$ 60$ and $\$ 103$, with an increase of $\$ 81$ being most likely.

During the period of our study, the earnings enhancing effects of increased child care subsidies appears to have more than offset the deteriorating labor market conditions associated with Florida's welfare reform and the minimum wage increase. Our estimates suggest that the net effect of the increase in child care subsidies and the simultaneous implementation of welfare reform and the minimum wage increase were associated with a change in monthly earnings of between $-\$ 18$ and $\$ 68$, with an earnings gain of $\$ 25$ most likely.

Further, our estimates indicate that higher rates of increase in parental co-payments for child care are associated with lower earnings, all other things equal. While the sign of the coefficient on the co-payment rate is consistently negative, it is not significant when the fixedeffects estimator is used. 
Estimates obtained using the unstructured random-effects estimator show no significant - impact on earnings of the availability of ECE or United Way child care programs. Results for the fixed-effects estimator indicate possibly beneficial effects of the availability of some types of Head Start programs.

\section{Administrative Variables}

We have weak evidence that the presence of employment counselors and lower caseloads at "one-stop" centers lead to increases in the earnings of working poor families. Caseloads at one-stop centers appear to have no significant effect on earnings.

\section{Human Capital and Socio-Demographic Variables}

More education is consistently associated with higher earnings. ${ }^{7}$ This result is significant for both random-effects estimators, but not for the fixed-effects estimator. Results obtained with the unstructured random-effects estimator indicate than an additional year of education is associated with an increase in earnings of $\$ 14$ per month.

Some care should be exercised when interpreting this result. Recall that we have only a year of data on the families in our sample. During this year, we do observe increases in education. However, there is insufficient variability over the year to yield a significant coefficient estimate. The education coefficient obtained with the fixed-effects estimator, which uses only variation within a family, is insignificantly different from the coefficient estimate of our preferred estimator. However, the fixed-effects coefficient is not significant at any normal level of statistical significance.

Most welfare reforms, including Florida's, downplay education and push for direct job training and work experience. This represents a change in emphasis from earlier welfare to work programs and may have important implications for the long-term ability of low-income workers to escape poverty. Clearly, work with longitudinal data that extends for a longer period of time would be valuable. It could provide more unambiguous evidence of the likely effect of increases in education for particular individuals.

${ }^{7}$ We also estimated specifications with a binary for high school graduation and specifications with the squared value of education. The coefficients on these variables were insignificantly different from zero. 
Results for other socio-demographics are interesting, but not of central concern to this paper. We find that being female is associated with lower earnings, but we find no significant racial/ethnic or language effects on earnings. The lack of a language effect may be somewhat surprising until one realizes that Miami is truly a bilingual city with Spanish being spoken at least as widely as English. For example, English is the family language of only about half of the working poor families in our sample. Recall also that $55 \%$ of the total population in Dade was Latino in 1996. Families with more children have higher earnings, all other things equal although there is weak evidence that the addition of a child to the family lowers earnings. Our results also provide evidence that a change in marital status lowers earnings. Neither the age of the youngest child in the household nor the availability of family/relative care has a significant effect on earnings.

Further, results obtained using random-effects estimators indicate that age has no significant effect on earnings. Results obtained using the fixed-effects estimator yield a normal and significant age-earnings profile. The fixed-effects estimates indicate that earnings increase with age until the age of 44 and decline thereafter. Because the fixed-effects estimator uses only variation in deviations from family-specific means, these estimates represent not cohort effects, but rather the true effect of age on earnings. Recall also that the random-effects estimators use the full information contained in both the time series and cross-sectional variation in the data. The coefficients on age obtained with random-effects estimators will, thus, reflect both true age effects and cohort effects. Cohort effects for US women born during the post World War II period are generally negative, with younger cohorts (e.g., women born during the 1970s) generally earning more (other things equal) than older cohorts (e.g., women born during the late 1940s and 1950s). The random-effects estimates reported in Table 3 indicate that age has no significant effect on earnings because they reflect countervailing true age effects and cohort effects.

\section{Costs of Working}

In our specification, we include prices for the major inputs used in child care (labor and space) and price indices for transportation, and clothing and apparel costs to reflect the costs of working. We use factor prices rather than child care prices because many reasonable models indicate that the earnings of families with children and the price of child care are jointly 
determined. Since we rely heavily on random-effects estimators, it is important that we not include potentially endogenous variables such as child care prices as explanatory variables.

We find that only higher earnings of child care workers have consistently significant effects on the earnings of working poor families. We find that a $10 \%$ increase in the median earnings of child care workers leads to a $0.8 \%$ decline in the earnings of the working poor members of our sample.

\section{Labor Market Conditions}

We find that the availability of jobs in industries where low-income workers are predominantly employed has a significant effect on the earnings of low-income workers. Most low-income workers in Dade County are employed in retail \& wholesale trade, services, nondurable manufacturing and by various levels of government (Griesinger, et al. ,1997). We find evidence that increases in the jobs available in retail and wholesale trade are associated with significantly higher earnings for the low-income workers in our sample, while increases in jobs available in services are associated with a significantly lower earnings.

\section{Community Fixed Effects}

Community fixed-effects are a highly significant determinant of the earnings of working poor families in Dade County. ${ }^{8}$ In general, the results for community fixed-effects indicate that the earnings of working poor families will be higher when the family lives in a mixed-income, suburban community such as South Miami and lower when the family lives in a rural agricultural community such as Florida City.

\section{Conclusions}

We find evidence that the simultaneous implementation of welfare reform and the increase in the minimum wage resulted in a decrease in the earnings of the working poor. While our substantive results should only be considered suggestive, they do provide some food for thought. Welfare reform has focused policy and research interest on the families that receive cash assistance. Moreover, federal income tax law has been amended to provide businesses with generous tax credits for employing individuals receiving cash assistance. Various business 
organizations (e.g., the U.S. Chamber of Commerce and the Greater Miami Chamber of Commerce) have established task forces to seek more jobs for individuals currently receiving cash assistance. Our work indicates that welfare reform and the emphasis on finding jobs for welfare recipients impacts not only poor families receiving cash assistance but also the many often equally poor families that do not receive cash assistance.

Our research suggests that the early stages of welfare reform may have negatively impacted the earnings of poor families who do not receive public assistance. We hypothesize that this detrimental effect results from increased competition in the low-skill labor market from previous welfare recipients. Further research is needed to determine if the results we obtain are broadly present. Economic theory would suggest that they might well be.

Our work highlights the need to think more broadly about helping all poor families to achieve economic self sufficiency, not just welfare families. Katz (1998) points out that targeted job subsidies, such as those designed to stimulate jobs for welfare recipient, are likely to be less efficient than broader subsidies designed to stimulate demand for all low-skill workers because the targeted group may be stigmatized in the process. Our results suggest that not only may the targeted group be stigmatized but that the group for whom subsidies are not available may suffer earnings declines.

Our results for Child Care Subsidies show that it is possible for more broadly based programs to help to stem the adverse effects of welfare reform on the working poor. Indeed, many states have used the increased funding available in these early stages of welfare reform to expand the availability of Income-Eligible Child Care Subsidies. Some states such as Illinois have even severed the link between the receipt of cash assistance and automatic eligibility for Child Care Subsidies.

After carefully surveying the literature, a number of prominent labor economist recently suggested that helping poor families achieve economic self sufficiency requires both skill upgrading and generating more jobs for less skilled workers (Freeman and Gottschalk, 1998). Our findings provide further support for these conclusions.

From a methodological perspective, we hope that we have demonstrated advantages of using a number of different estimating techniques when analyzing longitudinal data. While we

${ }^{8}$ For space considerations, we suppress the coefficient estimates associated with the community fixed effects. These are available from the authors upon request. 
believe that an unstructured random-effects estimator best fits our data, we also provide estimates obtained with the more commonly used fixed-effects estimator and the structured random-effects estimator. Comparison of estimates across estimation technique provides valuable evidence regarding the robustness of results. Such comparisons also can help to sort out such things as true age effects from cohort effects. Finally, results for the unstructured randomeffects estimator suggest strongly that models that allow a decline in the correlation of behavior over time may be more appropriate than traditional models that imposed a constant correlation of behaviors over time. 


\section{REFERENCES}

Abowd, John , Francis Kramarz, Thomas Lemieux and David Margolis, "Minimum Wages and Youth Employment in France and the United States," NBER Working Paper \#6111, 1997.

Blank, Rebecca, It Takes a Nation, (New York: Russell Sage, 1997).

Blank, Rebecca and Patricia Ruggles, "When Do Women Use Aid to Families with Dependent Children and Food Stamps," Joumal of Human Resources, 31 (1996), 37-89.

Card, David \& Alan Krueger, "A Reanalysis of the Effect of the New Jersey Minimum Wage Increase On The Fast-Food Industry with Representative Payroll Data," NBER Working Paper \#6386, 1998.

Card, David and Alan Krueger, Myth and Measurement: The New Economics of the Minimum Wage, (Princeton, NJ: Princeton University Press, 1995).

Card, David and Alan Krueger, "A Reanalysis of the Effect of The New Jersey Minimum Wage Increase on the Fast-Food Industry with Representative Payroll Data," NBER Working Paper 6386, 1998.

Chamberlain, Gary, "Panel Data," in Zvi Griliches and Michael Intrilligator (eds), Handbook of Econometrics, Vol. II (Amsterdam: North-Holland, 1983) 12471317.

Dade County Public Schools, Food Service Accounting Statistics for Academic Years 1995-96, 1996-97.

Eissa, Nada and Jeffrey Liebman, "Labor Supply Response to the Earned Income Tax Credit," Quarterly Journal of Economics, 111 (1996) 606-637.

Freeman, Richard and Peter Gottschalk (eds.), Generating Jobs: How to Increase Demand for Less-Skilled Workers (New York: Russell Sage, 1998).

Greene, William, Econometric Analysis, 3rd ed. (Upper Saddle River, NJ: Prentice Hall, 1997).

Katz, Lawrence, "Wage Subsidies for the Dasadvantaged," in Richard Freeman and Peter Gottschalk (eds.), Generating Jobs:How to Increase Demand for LessSkilled Workers (New York: Russell Sage, 1998) 21-53.

Leamer, E., "Model Choice and Specification Analysis," in Zvi Griliches and Michael Intrilligator (eds), Handbook of Econometrics, Vol. II (Amsterdam: NorthHolland, 1983) 286-330. 
Liang, K.-Y. and S. L. Zeger, "Longitudinal data analysis for discrete and continuous outcomes," Biometrics, 42 (1986) 121-130.

Liang, K.-Y.,S. Zeger, and B. Qaqish, "Multivariate regression analyses for categorical data," Journal of the Royal Statistical Society, Series B 54 (1992), 3-40.

Eissa, Nada and Jeffrey Liebman, "Labor Supply Response $t$ the Earned Income Tax Credit," Quarterly Journal of Economics, 111 (1996) 606-637.

Griesinger, Harriet, Ann Witte and Tasneem Chipty, "Employment of Parents Receiving Subsidized Child Care in Dade County, Florida," working paper Wellesley/FIU Child Care Research Partnership, 1997.

Hamilton, Gayle, Thomas Brock, Mary Farrell, Daniel Friedlander, and K. Harknett, National Evaluation of Welfare-to-Work Strategies (Washington, DC: US Department of Health \& Human Services and US Department of Education, 1997).

Harris, Kathleen, "Work and Welfare among Single Mothers in Poverty," American Journal of Sociology, 9 (1996) 407-426.

Holcomb, Pamela, LaDonna Pavetti, Caroline Ratcliffe and Susan Rieddinger, Building an Employment Focused Welfare system: Work First and Other Work-Oriented Strategies in Five States (Washington, DC: the Urban Institute, 1998).

Kim, Marlene and Thanos Mergoupis, "The Working Poor and Welfare Recipiency: Participation, Evidence, and Policy Directions," Journal of Economic Issues, 31 (1997) 707-728.

Leamer Edward, "Model Choice and Specification Analysis," in Zvi Griliches (eds.), Handbook of Econometrics (Amsterdam: North-Holland, 1983) 286-330.

Meyer, Bruce and Dan Rosenbaum, "Welfare, the Earned Income Tax Credit and the Labor Supply of Single Mothers," Paper presented at NBER, November 12, 1997.

Moffitt, Robert, "Incentive Effects of the U.S. Welfare System: A Review," Journal of Economic Literature, 30 (1992) 1-61.

Pavetti, LaDonna and Gregory Acs, "Moving Up, Moving Out or Going Nowhere?: A Study of the Employment Patterns of Young Women," report to the Annie E. Casey Foundation, July, 1997.

Portes, Alejandro and Alex Stepick, City on the Edge: The Transformation of Miami, (Berkeley, CA: University of California Press, 1993). 
State of Florida Jobs \& Benefits, Region VIII, Job Growth Rates by Industry Groups, March 1996 to February 1997 (provided by Ray Cade), 1997a.

State of Florida, Department of Children \& Families, Fiscal Year 1996 and 1997 Accounting Records (provided by Jim Cosper), $1997 \mathrm{~b}$.

U.S. Bureau of the Census, 1990 Census Of Population And Housing (CD90-3A-26 Summary Tape File 3A), 1995.

U.S. Bureau of the Census, Small Area Income And Poverty Estimates Program (Table 093-12), 1997.

U.S. Bureau of Labor Statistics. Table 6. Consumer Price Index for Urban Wage Earners and Clerical Workers (CPI-W). Selected areas, all items index. September 15, 1997. Available: http://stats.bls.gov/news.release/cpi.to6.htm (29 Sept 1997).

Witte, Ann, Magaly Queralt, Harriet Griesinger and Tasneem Chipty, "Impact of Child Care Subsidies and Welfare Reform on Employment and Earnings: A Longitudinal Study of Low-Income Families in Dade County, Florida," Briefing Report 2, Tri-State Child Care Research Partnership, Miami, Fl, 1998. 
Table 1

Definition of Variables and Sources

\begin{tabular}{|c|c|c|}
\hline$\frac{\text { THEORETICAL }}{\text { CONSTRUCT }}$ & EMPIRICAL MEASURE & SOURCE \\
\hline \multicolumn{3}{|c|}{ Dependent Variable } \\
\hline Earnings & Monthly Earnings on all jobs & $\begin{array}{c}\text { Dade County Income-Eligible } \\
\text { Subsidy Files }\end{array}$ \\
\hline \multicolumn{3}{|c|}{ Explanatory Variables } \\
\hline \multicolumn{3}{|l|}{ 1. Policy Variables } \\
\hline $\begin{array}{r}\text { Welfare Reform/Minimum } \\
\text { Wage Increase }\end{array}$ & $\begin{array}{l}\text { A Binary Equal to One after } \\
\text { Welfare Reform and the Minimum } \\
\text { Wage Increase and Zero Before }\end{array}$ & $\begin{array}{l}\text { Administrative Records and } \\
\text { Income-Eligible Subsidy Files }\end{array}$ \\
\hline \multicolumn{3}{|c|}{ Child Care Subsidy Variables } \\
\hline $\begin{array}{r}\text { State/Federal Child Care } \\
\text { Subsidies }\end{array}$ & $\begin{array}{l}\text { State \& Federal Child Care } \\
\text { Subsidy Funding per Eligible Child }\end{array}$ & $\begin{array}{l}\text { Department of Children \& } \\
\text { Families Accounting Records, } \\
1990 \text { US Census and Dade } \\
\text { County Public Schools Food } \\
\text { Service Accounting Records }\end{array}$ \\
\hline Parental Co-Payments & $\begin{array}{l}\text { Average Rate at which Parental } \\
\text { Co-payments Increase as Earnings } \\
\text { Increase }\end{array}$ & $\begin{array}{c}\text { Department of Children \& } \\
\text { Families Administrative } \\
\text { Records }\end{array}$ \\
\hline $\begin{array}{l}\text { Lower Co-Payments for } \\
\text { Second and Subsequent } \\
\text { Children Receiving care } \\
\end{array}$ & $\begin{array}{l}\text { A Binary Variable Equal to One if } \\
\text { More Than One Child in the } \\
\text { Family Is in Subsidized Care }\end{array}$ & $\begin{array}{c}\text { Department of Children \& } \\
\text { Families Administrative } \\
\text { Records } \\
\end{array}$ \\
\hline $\begin{array}{l}\text { Private Child Care/Child } \\
\text { Development Subsidies }\end{array}$ & $\begin{array}{l}\text { United Way Subsidy per Eligible } \\
\text { Child in Zip Code }\end{array}$ & $\begin{array}{c}\text { Accounting \& Programmatic } \\
\text { Records United Way of Dade } \\
\text { County }\end{array}$ \\
\hline \multicolumn{3}{|c|}{ Early Childhood Education Variables } \\
\hline Head Start & $\begin{array}{l}\text { Capacity-Vacancies in CAA Head } \\
\text { Start Centers in Zip Code/number } \\
\text { of children } 5 \& \text { under in poverty in } \\
\text { zip code }\end{array}$ & $\begin{array}{l}\text { Head Start Center data Dade } \\
\text { County R\&R files and Dade } \\
\text { County's Community Action } \\
\text { Agency (CAA)/ } 1990 \text { census }\end{array}$ \\
\hline & $\begin{array}{l}\text { Capacity-Vacancies in Head Start } \\
\text { Centers in Public Schools in Zip } \\
\text { Code/number of children } 5 \text { \& under } \\
\text { in poverty in zip code }\end{array}$ & $\begin{array}{c}\text { Head Start Center data from } \\
\text { Dade County R\&R files and } \\
\text { Dade County Public } \\
\text { Schools/1990 census } \\
\end{array}$ \\
\hline & $\begin{array}{l}\text { Capacity-Vacancies in Head Start } \\
\text { Centers with Wrap Around Care in } \\
\text { Zip Code/number of children } 5 \& \\
\text { under in poverty in zip code }\end{array}$ & $\begin{array}{c}\text { Head Start Center data from } \\
\text { Dade County R\&R / } 1990 \\
\text { census }\end{array}$ \\
\hline Pre-Kindergarten (Pre-K) & $\begin{array}{l}\text { Capacity-Vacancies of Pre-Ks with } \\
\text { Zero Price in Zip Code/number of } \\
4 \text { year old children in poverty in zip } \\
\text { code }\end{array}$ & $\begin{array}{l}\text { Pre-K data from Dade County } \\
\text { R\&R files and Dade County } \\
\text { Public Schools } / 1990 \text { census }\end{array}$ \\
\hline $\begin{array}{r}\text { Other Child Care Programs in } \\
\text { Public Schools }\end{array}$ & $\begin{array}{l}\text { Capacity-Vacancies of Public } \\
\text { School Child Care with Fees in Zip } \\
\text { Code/number of children }<=13 \text { in } \\
\text { zip code }\end{array}$ & $\begin{array}{l}\text { Pre-K data from Dade County } \\
\text { R\&R files and Dade County } \\
\text { Public Schools/1990 census }\end{array}$ \\
\hline
\end{tabular}




\section{Administrative Variables}

\begin{tabular}{|c|c|c|}
\hline One Stops & $\begin{array}{l}\text { Number of Programs } \\
\text { Administered by the Local } \\
\text { Eligibility Determination Office }\end{array}$ & $\begin{array}{c}\text { Interview with Local } \\
\text { Eligibility Determination } \\
\text { Offices }\end{array}$ \\
\hline & $\begin{array}{l}\text { A Binary Equal to One if the } \\
\text { Local Eligibility Determination } \\
\text { Office Has an Employment } \\
\text { Counselor }\end{array}$ & $\begin{array}{c}\text { Interview with Local } \\
\text { Eligibility Determination } \\
\text { Offices, Summer } 1997\end{array}$ \\
\hline Caseload & $\begin{array}{l}\text { Number of Clients per Worker } \\
\text { at Eligibility Determination } \\
\text { Office }\end{array}$ & $\begin{array}{c}\text { Interview with Local } \\
\text { Eligibility Determination } \\
\text { Offices }\end{array}$ \\
\hline
\end{tabular}

\section{Human Capital/Socio-Demographic Variables}

\begin{tabular}{|c|c|c|}
\hline Age & $\begin{array}{l}\text { Age of the Subsidy Recipient } \\
\text { and the Squared Value of Age }\end{array}$ & $\begin{array}{l}\text { Dade County Income- } \\
\text { Eligible Subsidy Files }\end{array}$ \\
\hline Education & $\begin{array}{l}\text { Subsidy Recipients Years of } \\
\text { Education }\end{array}$ & $\begin{array}{l}\text { Dade County Income- } \\
\text { Eligible Subsidy Files }\end{array}$ \\
\hline Gender & $\begin{array}{l}\text { A Binary Equal to One if } \\
\text { Subsidy Recipient Is Female and } \\
\text { Zero Otherwise }\end{array}$ & $\begin{array}{l}\text { Dade County Income- } \\
\text { Eligible Subsidy Files }\end{array}$ \\
\hline Current Marital Status & $\begin{array}{l}\text { A Binary Equal to One if } \\
\text { Subsidy Recipient Is Currently } \\
\text { Married and Zero Otherwise }\end{array}$ & $\begin{array}{l}\text { Dade County Income- } \\
\text { Eligible Subsidy Files }\end{array}$ \\
\hline Previous Marital Status & $\begin{array}{l}\text { A Binary Equal to One if } \\
\text { Subsidy Recipient is Separated, } \\
\text { Divorced, or Widowed and } \\
\text { Zero Otherwise }\end{array}$ & $\begin{array}{l}\text { Dade County Income- } \\
\text { Eligible Subsidy Files }\end{array}$ \\
\hline Language & $\begin{array}{l}\text { A Binary Equal to One if Family } \\
\text { Language Is English and Zero } \\
\text { Otherwise }\end{array}$ & $\begin{array}{l}\text { Dade County Income- } \\
\text { Eligible Subsidy Files }\end{array}$ \\
\hline Race & $\begin{array}{l}\text { A Binary Equal to One if } \\
\text { Subsidy Recipient Is Black and } \\
\text { Zero Otherwise }\end{array}$ & $\begin{array}{l}\text { Dade County Income- } \\
\text { Eligible Subsidy Files }\end{array}$ \\
\hline \multirow[t]{2}{*}{ Ethnicity } & $\begin{array}{l}\text { A Binary Equal to One if } \\
\text { Subsidy Recipient is Hispanic } \\
\text { and Zero Otherwise }\end{array}$ & $\begin{array}{l}\text { Dade County Income- } \\
\text { Eligible Subsidy Files }\end{array}$ \\
\hline & $\begin{array}{l}\text { A Binary Equal to One if } \\
\text { Subsidy Recipient is Haitian and } \\
\text { Zero Otherwise }\end{array}$ & $\begin{array}{l}\text { Dade County Income- } \\
\text { Eligible Subsidy Files }\end{array}$ \\
\hline Number of Children & $\begin{array}{l}\text { Total Number of Children }<18 \\
\text { Resident in Family }\end{array}$ & $\begin{array}{l}\text { Dade County Income- } \\
\text { Eligible Subsidy Files }\end{array}$ \\
\hline Age of Youngest Child & $\begin{array}{l}\text { Age in Years of Youngest Child } \\
\text { in the Family }\end{array}$ & $\begin{array}{l}\text { Dade County Income- } \\
\text { Eligible Subsidy Files }\end{array}$ \\
\hline Availability of Informal Care & $\begin{array}{l}\text { A Binary Equal to One if } \\
\text { Receives Voucher or Has } \\
\text { Individual Age> } 13 \text { in } \\
\text { Household and Zero Otherwise }\end{array}$ & $\begin{array}{l}\text { Dade County Income- } \\
\text { Eligible Subsidy Files }\end{array}$ \\
\hline
\end{tabular}


4. Costs of Working

\begin{tabular}{||r|l|c|}
\hline Costs of Child Care & $\begin{array}{l}\text { Median Quarterly Earnings of } \\
\text { Child Care Workers in Zip Code }\end{array}$ & $\begin{array}{c}\text { Florida Department of } \\
\text { Labor Es202 Files }\end{array}$ \\
\hline & $\begin{array}{l}\text { Median Rent Per Room of } \\
\text { Houses in Zip Code }\end{array}$ & $\begin{array}{c}\text { US Census of Housing, } \\
1990\end{array}$ \\
\hline Transportation Costs & Price Index for Transportation & $\begin{array}{c}\text { US Bureau of Labor } \\
\text { Statistics, CPI-W- } \\
\text { Transportation Cost Index }\end{array}$ \\
\hline & Mean Travel Time to Work for & $\begin{array}{c}\text { US Census of Population, } \\
1990\end{array}$ \\
\hline Clothing Costs & Price Index for Clothing & $\begin{array}{c}\text { US Bureau of Labor } \\
\text { Statistics, CPI-W- } \\
\text { Clothing \& Apparel Cost } \\
\text { Index }\end{array}$ \\
\hline
\end{tabular}

\section{Local Labor Market Conditions}

\begin{tabular}{|c|c|c|}
\hline $\begin{array}{r}\text { Availability of Low-Skill } \\
\text { Jobs }\end{array}$ & $\begin{array}{l}\text { Employment Growth Rates in } \\
\text { (1) Non-durable Manufacturing, } \\
\text { (2) Retail \& Wholesale Trade, } \\
\text { (3) Personal, Business \& Health } \\
\text { Services \& (4) Government }\end{array}$ & $\begin{array}{l}\text { Florida Jobs \& Benefits, } \\
\text { Region VIII }\end{array}$ \\
\hline
\end{tabular}

\section{Community Effects}

Community Fixed Effects
A Set of 22 Community Specific Binaries Equal to One if the Subsidy Recipient Resides in the Community and Zero Otherwise
Metro-Dade Taxing Jurisdictions and Maptitude GIS Software 
Table 3

Results Monthly Family Earnings of Working Poor

$(n=24,361)$

\begin{tabular}{|c|c|c|c|c|c|c|c|c|c|}
\hline \multirow[b]{3}{*}{ Explanatory Variables } & \multicolumn{6}{|c|}{ Full Specification } & \multirow{2}{*}{\multicolumn{3}{|c|}{\begin{tabular}{|c|} 
Reduced Specification \\
Random Effects \\
Unstructured Error
\end{tabular}}} \\
\hline & \multirow{2}{*}{\multicolumn{2}{|c|}{ Fixed Effects }} & \multirow{2}{*}{\multicolumn{2}{|c|}{$\begin{array}{l}\text { Random Effects } \\
\text { Structured Error } \\
\text { Coefficient } P \geq|z|\end{array}$}} & \multirow{2}{*}{\multicolumn{2}{|c|}{$\begin{array}{l}\text { Random Effects } \\
\text { Unstructured Error } \\
\text { Coefficient } P \geq|z|\end{array}$}} & & & \\
\hline & & & & & & & \multicolumn{2}{|c|}{ Coefficient $P>|z|$} & Elasticity \\
\hline \multicolumn{10}{|l|}{ Policy Variables } \\
\hline $\begin{array}{l}\text { Binary for Welfare Reform/Minimum Wage Increase } \\
\text { Subsidy Variables: }\end{array}$ & -0.040 & 0.00 & -0.057 & 0.00 & -0.058 & 0.00 & -0.056 & 0.01 & \\
\hline State/Federal Child Care Subsidiesí & 0.002 & 0.00 & 0.002 & 0.00 & 0.002 & 0.00 & 0.002 & 0.00 & 0.45 \\
\hline Rate of Increase in Copaymentsi & -3.389 & 0.18 & -8.303 & 0.00 & -6.081 & 0.01 & -6.972 & 0.00 & -0.26 \\
\hline Binary for Copayments Reduction $>1$ Child & -0.025 & 0.04 & -0.020 & 0.37 & -0.026 & 0.07 & -0.027 & 0.05 & \\
\hline United Way Subsidy per Eligible Child $(\$ 100)$ & -0.036 & 0.21 & -0.006 & 0.75 & 0.004 & 0.82 & & & \\
\hline \multicolumn{10}{|l|}{ Early Childhood Education Programs: } \\
\hline Availability of Head Start Slots in Public Schools! & 0.057 & 0.68 & 0.128 & 0.16 & 0.071 & 0.40 & & & \\
\hline Availability of CAA Head Start Slots & 0.025 & 0.02 & 0.010 & 0.29 & 0.004 & 0.68 & & & \\
\hline Availability of Wrap Around Head Start Slotsi & 0.171 & 0.04 & 0.101 & 0.20 & 0.047 & 0.52 & & & \\
\hline Availability of Free Pre-K slotsi & -0.046 & 0.27 & -0.037 & 0.51 & -0.005 & 0.87 & & & \\
\hline Availability of Paid Public School Child Care ! & 2.969 & 0.17 & 0.973 & 0.72 & -0.940 & 0.65 & & & \\
\hline \multicolumn{10}{|l|}{ Administrative Variables } \\
\hline Number of Programs at "One Stops"i & -0.008 & 0.81 & -0.020 & 0.66 & 0.010 & 0.82 & & & \\
\hline Binary for Employment Couselor at One Stopsí & 0.000 & 0.02 & 0.020 & 0.31 & 0.030 & 0.07 & 0.030 & 0.08 & \\
\hline Clients per Eligibility Counselor (100s) & 0.030 & 0.15 & 0.016 & 0.58 & -0.040 & 0.08 & -0.034 & 0.11 & -0.11 \\
\hline \multicolumn{10}{|l|}{ Human Capital and Socio-Demographic } \\
\hline Age in Years! & 0.219 & 0.00 & -0.004 & 0.73 & -0.008 & 0.39 & & & \\
\hline Age in years squared & -0.002 & 0.00 & 0.000 & 0.87 & 0.000 & 0.56 & & & \\
\hline Years of Education & 0.013 & 0.33 & 0.015 & 0.00 & 0.014 & 0.00 & 0.014 & 0.00 & 0.16 \\
\hline Femaleí & \multicolumn{2}{|c|}{ No Esimate } & -0.091 & 0.04 & -0.087 & 0.05 & -0.075 & 0.08 & \\
\hline Marriedí & -0.146 & 0.00 & -0.054 & 0.22 & -0.05 & -0.28 & & & \\
\hline Previously Married! & -0.038 & 0.01 & -0.008 & 0.66 & 0.004 & 0.84 & & & \\
\hline English Is Family Language! & -0.11 & 0.027 & 0.024 & 0.36 & 0.032 & 0.16 & 0.046 & 0.03 & \\
\hline Hispanic! & No Esim & late & -0.037 & 0.39 & -0.027 & 0.50 & & & \\
\hline Black! & No Esim & late & -0.091 & 0.05 & -0.070 & 0.11 & -0.053 & 0.02 & \\
\hline Haitian & No Esim & ate & 0.000 & 0.99 & 0.001 & 0.98 & & & \\
\hline Number of Children in Family & -0.017 & 0.373 & 0.058 & 0.00 & 0.071 & 0.00 & 0.069 & 0.00 & 0.16 \\
\hline Age in Years of Youngest Childi & 0.009 & 0.22 & 0.004 & 0.42 & 0.002 & 0.75 & & & \\
\hline Informal Care Available! & 0.025 & 0.28 & 0.016 & 0.66 & 0.024 & 0.38 & & & \\
\hline \multicolumn{10}{|l|}{ Costs of Working } \\
\hline Median rent per room & 0.002 & 0.00 & 0.001 & 0.35 & 0.000 & 0.89 & & & \\
\hline Median Earnings of Child Care Workers $(\$ 100 s) i$ & -0.004 & 0.063 & -0.006 & 0.10 & -0.010 & 0.01 & -0.010 & 0.01 & -0.08 \\
\hline Mean Travel Time to Work & 0.003 & 0.31 & 0.001 & 0.77 & -0.002 & 0.70 & & & \\
\hline Transportation Costs! & -0.003 & 0.17 & -0.002 & 0.29 & 0.004 & 0.46 & & & \\
\hline Clothing Costs! & 0.000 & 0.387 & 0.000 & 0.67 & 0.001 & 0.05 & 0.001 & 0.03 & 0.12 \\
\hline \multicolumn{10}{|l|}{ Local Labor Market } \\
\hline Employment Growth-nondurable manufacturing & -0.011 & 0.152 & -0.019 & 0.00 & -0.013 & 0.20 & -0.016 & 0.01 & 0.00 \\
\hline Employment Growth-retail \& wholesale trade & 0.011 & 0.035 & 0.018 & 0.00 & 0.013 & 0.00 & 0.016 & 0.00 & 0.00 \\
\hline Employment Growth-services! & -0.009 & 0.04 & -0.141 & 0.00 & -0.012 & 0.10 & -0.013 & 0.00 & 0.00 \\
\hline Employment Growth-government! & 0.001 & 0.41 & 0.000 & 0.43 & 0.000 & 0.88 & & & \\
\hline Constant & 2.150 & 0.014 & 6.718 & 0.00 & 6.687 & 0.00 & 6.400 & 0.00 & \\
\hline
\end{tabular}

